Omni-Akuatika, 15 (1): 75-80, 2019
ISSN: 1858-3873 print / 2476-9347 online
Research Article
journal homepage: http://ojs.omniakuatikanet

\title{
Analysis of Heavy Metal Cadmium (Cd) on Mud Crab (Scylla sp.) at Wonorejo River Surabaya
}

\author{
Nanang Ardianto ${ }^{1}$, Prayogo $^{2}$ dan Adriana Monica Sahidu ${ }^{2}$ \\ ${ }^{1}$ Aquaculture Study Program, Faculty of Marine and Fisheries, Universitas Airlangga, \\ JI. Mulyorejo Kampus C Unair, Surabaya60115, Indonesia \\ ${ }^{2}$ Department of Marine, Faculty of Marine and Fisheries, Universitas Airlangga, Jl. Mulyorejo Kampus C Unair, \\ Surabaya 60115, Indonesia \\ *Corresponding author: nanangardianto17121996@gmail.com
}

Received 9 July 2018; Accepted 19 April 2019; Available online 31 May 2019

\begin{abstract}
The coast of Wonorejo is part of eastern coastline in Surabaya that directly receives load of river current area (DAS) from another river. The main heavy metal source was taken at downstream part of Wonorejo river that cross several industries which they dump the waste to that river. One of main heavy metal which is a toxic element and potentially damage marine ecology system is cadmium (Cd). Mud crab is one of marine potential resource that could be fund among mangrove forest of Wonorejo river Surabaya that could accumulate heavy metal. The study was conducted on April 2018 that has three collecting sample process taken from three stations, the sample was taken once for a week, therefore it takes three weeks to collect all samples. The analysis of Cadmium (Cd) heavy metal on mud crab (Scylla sp.), water, and sediment was tested in nutrition laboratory of public health faculty of Airlangga University. The method of study uses observation which is held in fishpond and marine environment of Wonorejo, Surabaya. The mud crab flesh sample, water, and sediment are tested by using Atomic Absoption Spectrophotometry (AAS) tool. The result stated that cadmium heavy metal concentration found in mud crab sample of Wonorejo river is about $0,032 \mathrm{mg} \cdot \mathrm{kg}^{-1}$, the number is still under basic threshold of Cd heavy metal quality in crustaceans, the basic threshold is $1 \mathrm{mg} \cdot \mathrm{kg}^{-1}$ (SNI 7387: 2009). The Cd concentration of Wonorejo river is between 0,014-0,02ppm and the concentration on its sediment is between $0,234-0,416 \mathrm{mg} / \mathrm{kg}$. the correlation of cadmium concentration on the water and the mud crab flesh of Wonorejo river revealed its coefficient amount which is $-0,22$ (weak correlation and negative amount). Next, the correlation of cadmium concentration on the sediment and the mud crab flesh of Wonorejo river revealed its coefficient amount which is 0,285 (strong correlation and positive amount).
\end{abstract}

Keywords: Heavy metals, Cadmium, Scylla sp., AAS

\section{Introduction}

The coast of Wonorejo is part of eastern coastline in Surabaya that directly receives load of river current area (DAS) from another river. The Wonorejo river is potentially being accumulated with anthropogenic load as a result of river misuse for waste dumping area, whereas the waste load will be carried out from river mouth into stream of the sea (environment council of Surabaya, 2011).

One of main heavy metal which is a toxic element and potentially damage marine ecology system is cadmium (Cd). There is toxic concentration on the metal that will cause stability degradation of the ecology environment and the marine's life around it (Mamaribo, 2015). The latest result of cadmium concentration test in Wonorejo river was conducted by environment council of Surabaya in 2008-2009, the concentration was $0,05 \mathrm{mg} / \mathrm{L}$ which already exceed basic quality heavy metal waste concentration. Though, the concentration was decreased into $0,03 \mathrm{mg} / \mathrm{L}$ in 2011 .

Mud crab is one of marine potential resource that could be fund among mangrove forest of Wonorejo river Surabaya. The annual statistic report of fishery production of mud commodity in east java province, especially in Surabaya, reaches about 210 tons (fishery and marine office, 2014). The production was decreased into 184.69 tons in 2016 (food 
security and agricultural office of Surabaya, 2017).

According to the background of study above, the heavy metal found in Wonorejo river is assumed to contribute negative effect towards the existence of mud crub. Thus, the experiment to measure the amount of cadmium heavy metal on mud crab is important as it could be an information about the safety to consume the crab or to cultivate the mud crab around Wonorejo river of Surabaya.

\section{Materials and Methods}

\subsection{The Station determination and collecting sample}

The station determination to collect sample of water, sediment, and mud crab's flesh is preceded with a survey of the geographical condition and the activity around the experiment environment (Hadi, 2007). Next, the geographic coordinate determination of stations to collect samples is using Global Positioning System (GPS) tool. The map of every stations to collect the sample could be found in attachment 2. The coordinate of three stations are as follow, station 1 (7¹8'26.74"LS-11249'18.71"BT), station 2 (7'18'33.83"LS-112 $\left.50^{\prime} 1.29^{\prime \prime} \mathrm{BT}\right)$, dan station 3 (7¹8'19.67"LS-11250'40.05" BT).

Station 1: Taken at the front side of mangrove forest of Wonorejo river, it is about 2,2 $\mathrm{km}$ from estuary.

Station 2: Taken at the fish pound area which is in Wonorejo river nearby, it is about $1,3 \mathrm{~km}$ from estuary.

Station 3: Taken at the end of mangrove area of estuary which is in Wonorejo river nearby and ship cruise line.

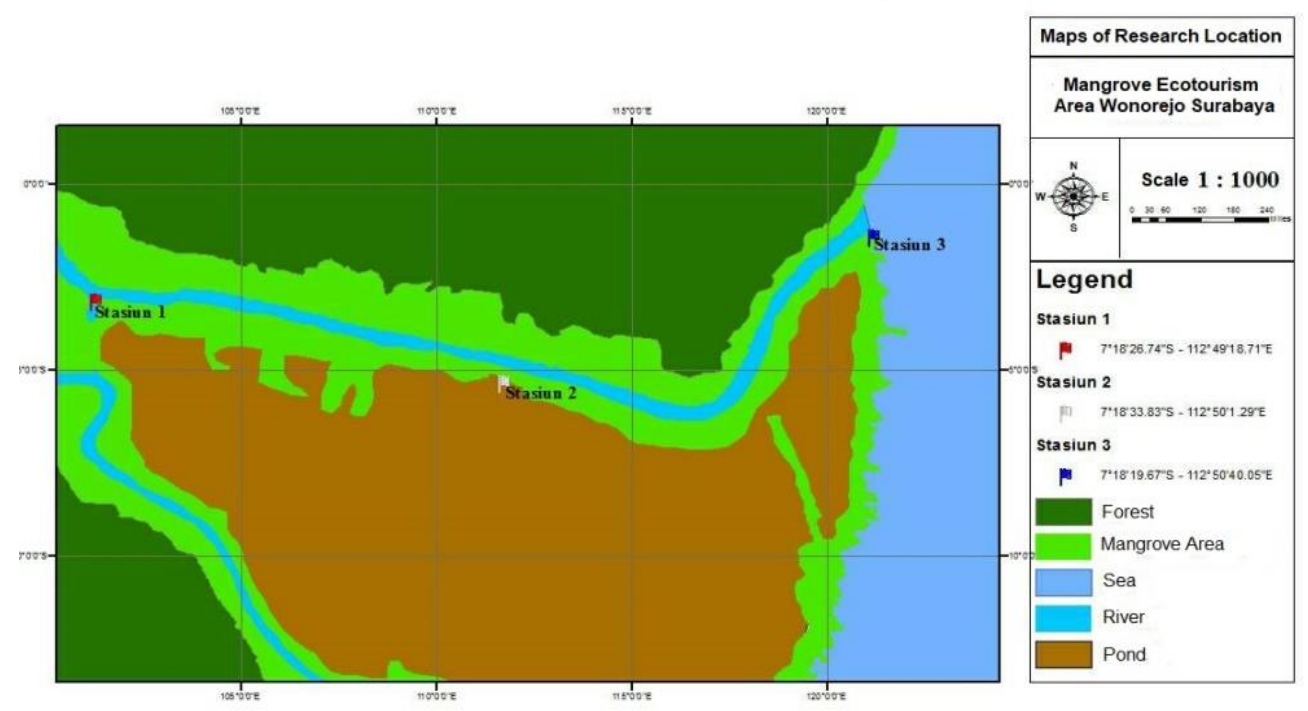

Figure 1. Research Setting Map

\subsection{Sample collecting}

The sample collecting of mud crab, water, and sediment is using simple random sample method.

\section{A. The mud crab sample}

The mud crab was taken when tide is in by installing traps in chosen place. Next, the trap that has caught mud crab is taken after the tide is out (WWF Indonesia, 2015). The existence of tide indicates puddle water in the ecosystem that could give direct impact for mud crabs. There are 10 mud crabs that are caught for each station, the size of carapace is about $9-12 \mathrm{~cm}$. The sample of mud crabs' flesh is taking out from its carapace by breaking it with crab carapace breaker tool. The flesh from all stations are being turned into homogenous sample, weighed them for about 50 gram, put them into a plastic bag to avoid contamination. After that, the sample is ready to be tested in laboratory to reveal its heavy metal concentration. 


\section{B. Water sample}

The water sample is collected by using water sampler technique below the water surface for about $50 \mathrm{ml}$ on each station. The bottles used as a container are put into cool box that has ice cubes inside to avoid chemical and biological alteration. The box is then firmly closed and being transported to laboratory to reveal its heavy metal concentration.

\section{Sediment sample}

The sediment taken out from each station are collected by using Ekman Grab technique within 10-25 cm depth from its surface. The amount of sediment needed for each station is 50 gram. The collected sample is put in plastic bag. The plastic bag as container is put into cool box that has ice cubes inside to avoid chemical and biological alteration. The box is then firmly closed and being transported to laboratory to reveal its heavy metal concentration.

\subsection{Cadmium heavy metal test}

The revelation of cadmium heavy metal on mud crab flesh, water, and sediment is using a tool called atomic absorption spectrophotometry (AAS) which its basic system take the advantage of the amount of light, the more sunlight being absorbed, the more element concentration within the sample (Erlangga, 2007).

Generally, the experiment by using AAS technique takes several procedures which are turning on the AAS circuit and adjust the hollow cathode lamp. Then, make sure that AAS is already connected to the computer, and connect it with standard solution and sample which are already made before. Next, the analysis of standard solution and sample are commenced, measure the absorption amount for each solution, create the absorption curve, and take a note of cadmium concentration in the sample.

\subsection{Data analysis}

The data od this study is displayed as cadmium (Cd) heavy metal concentration which is extracted from mud crab flesh, the water, and the sediment, it is then processed by correlation test through Statistical Product And Service Solution program (SPSS) 22 Version.

\section{Results and Discussion}

\subsection{Cadmium Concentration in The Water}

The cadmium heavy metal concentration found in three stations of Wonorejo river shows the number between $0,014-0,02 \mathrm{ppm}$ that already exceed maximum threshold policy which is stated in The Ministry of Environment Decision number 51 of 2004 about the basic quality of marine life which is $0,001 \mathrm{ppm}$. Though, the number had decreased through times which is found on previous studies conducted by Environment Council of Surabaya in 2008 which concludes the amount of it is $0,03 \mathrm{ppm}$.

The decrease of accumulated cadmium heavy meal concentration on the river could be caused by the rhizofiltration process which is derived from mangrove forest that is spread along the coastal line where the station takes place. Gunarto (2004), stated that mangrove posses the ability of bio filter to filter, bond, and catch pollution among natures such as over sedimentation, waste, household waste, thus it increases the water quality.

Another factor such as current also affects the fluctuation of heavy metal in river. Indrayana (2014), stated that current has its role in water's quality spread. The mixing process occurred in the water will be delivered to the currect direction. From the research data, it is revealed that the spread of cadmium is bigger found in estuary part as the sample was collected when the tide is in.

Table 1. the concentration average of cadmium (Cd) heavy metal found in mud crab flesh (Scylla sp.), water, and sediment of Wonorejo river of Surabaya.

\begin{tabular}{lccc}
\hline Sampling Point & $\begin{array}{c}\text { Mud Crab Flesh } \\
\left(\mathrm{mg}^{-\mathrm{kg}^{-1}}\right)\end{array}$ & $\begin{array}{c}\text { Water } \\
(\mathrm{ppm})\end{array}$ & $\begin{array}{c}\text { Sediment } \\
\left(\mathrm{mg}^{-1} \mathrm{~kg}^{-1}\right)\end{array}$ \\
\hline Station I & 0.024 & 0.02 & 0.416 \\
Station II & 0.04 & 0.018 & 0.234 \\
Station III & 0.032 & 0.014 & 0.313 \\
Average ( $\pm \mathrm{SD})$ & $0.032 \pm 0.008$ & $0.017 \pm 0.003$ & $0.321 \pm 0.091$ \\
\hline
\end{tabular}




\subsection{Cadmium Concentration in The Sediment}

The cadmium heavy metal concentration in sediment found in three stations of Wonorejo river shows the number between $0,234-0,416$ $\mathrm{mg} / \mathrm{kg}$ that does not exceed the threshold determined by ANZECC and ARMCANZ in 2000 about the basic quality of sediment in the water for marines environment which is $1,5-10$ $\mathrm{mg} / \mathrm{kg}$. This is occurred as sediment is easy to be suspend by the flow of water mass which is re-dissolved the heavy metal found in the water.

The sediment sampling result in three stations revealed that the concentration of cadmium amount is bigger than the element found in the water. Because, the density of cadmium is bigger than water density, thus the deposition is occurred from the water column into the bottom of the water (Widowati, 2008). The heavy metal experiences dilution process in the water and being deposition, thus the accumulation is occurred toward the sediment. Unfortunately, this would be a time bomb that could result in negative impact for marine's life that lives around the environment (Permanawati, 2012).

\subsection{Cadmium Concentration in Mud Crab Flesh}

The cadmium heavy metal concentration in mud crab flesh found in three stations of Wonorejo river shows the number between $0,024-0,041 \mathrm{mg} / \mathrm{kg}$. The number does not exceed Indonesian national standard threshold no. 7387 of 2009 about maximum threshold of cadmium heavy metal concentration in fishery product especially crustacean's flesh which is $1,0 \mathrm{mg} / \mathrm{kg}$. The result reveals that the mud crab in all setting of study is still safe to be consumed.

The heavy metal could travel from environment into the inside of organism body. Then, it is delivered from one organism to another through food chain (Yalchin et al., 2008). On marine's organism, the accumulation of heavy metal is increasing through times (Nowrouzi, et al., 2012). The study's result shows that the concentration of cadmium on mud crab flesh is still low, it could be caused by the age of sample is sill young when it is caught, and the size is medium, thus the accumulation of heavy metal process does not reach its maximum amount.

\subsection{Water Quality Parameter}

The parameters of water which is used to support the study include $\mathrm{pH}$, temperature, and salinity. The result of temperature condition while the experiment takes place, the surface level temperature of Wonorejo river of
Surabaya is about $28-30^{\circ} \mathrm{C}$. According to the Ministry of Environment number 51 of 2004, the genera temperature found in Indonesian marine environment is about $28-32^{\circ} \mathrm{C}$. The number of temperature found during the experiment is still on normal level for aquatic life.

Salinity amount found in Wonorejo river of Surabaya during the experiment is $0-6$ ppt. the amount of salinity of water could affect heavy metal concentration that pollute environment. The lower salinity level found in water environment, the higher heavy metal accumulation found among the organism that lives around environment (Muhktasor, 2007).

Measurement of $\mathrm{pH}$ of Wonorejo river of Surabaya reveals that the $\mathrm{pH}$ is basic and stable between 6-8 within average of 7,7 . According to those numbers, it is concluded that the Wonorejo river is still in line with NAB standard that is supported by Ministry of Environment number 51 of 2014. According to Fatmawatinir (2015), she stated that the concentration of cadmium heavy metal could increase when the state of $\mathrm{pH}$ is acidic and low that makes faster solution process for the heavy metal.

3.5 The Relation between Cadmium Concentration And Mud Crab Flesh, Water, And Sediment

Simple regression test result in order to reveal the correlation between cadmium concentration of water and mud crab flesh shows weak result with negative correlation direction $(R=-0,22)$. This concludes that the water of Wonorejo river does not give significant impact towards the concentration of cadmium found in mud crab flesh.

Meanwhile, the correlation between cadmium concentrations of sediment and mud crab flesh also shows weak result with positive correlation direction $(R=0,285)$. This concludes that the water of Wonorejo river does not give significant impact towards the concentration of cadmium found in mud crab flesh. Though, the number is positive, it means that the higher cadmium concentration of sediment, the higher cadmium found in mud crab flesh.

The weak correlation between variable of water and sediment with mud crab flesh concludes that the concentration of cadmium heavy metal found in mud crab flesh (Scylla sp.) of Wonorejo river of Surabaya is affected by another factors. These factors could be water quality, season, physical condition of the water, bi remediation of mangrove and biologic characteristics of the mud crab (Scylla sp.). Those correlations are displayed in figure 2 

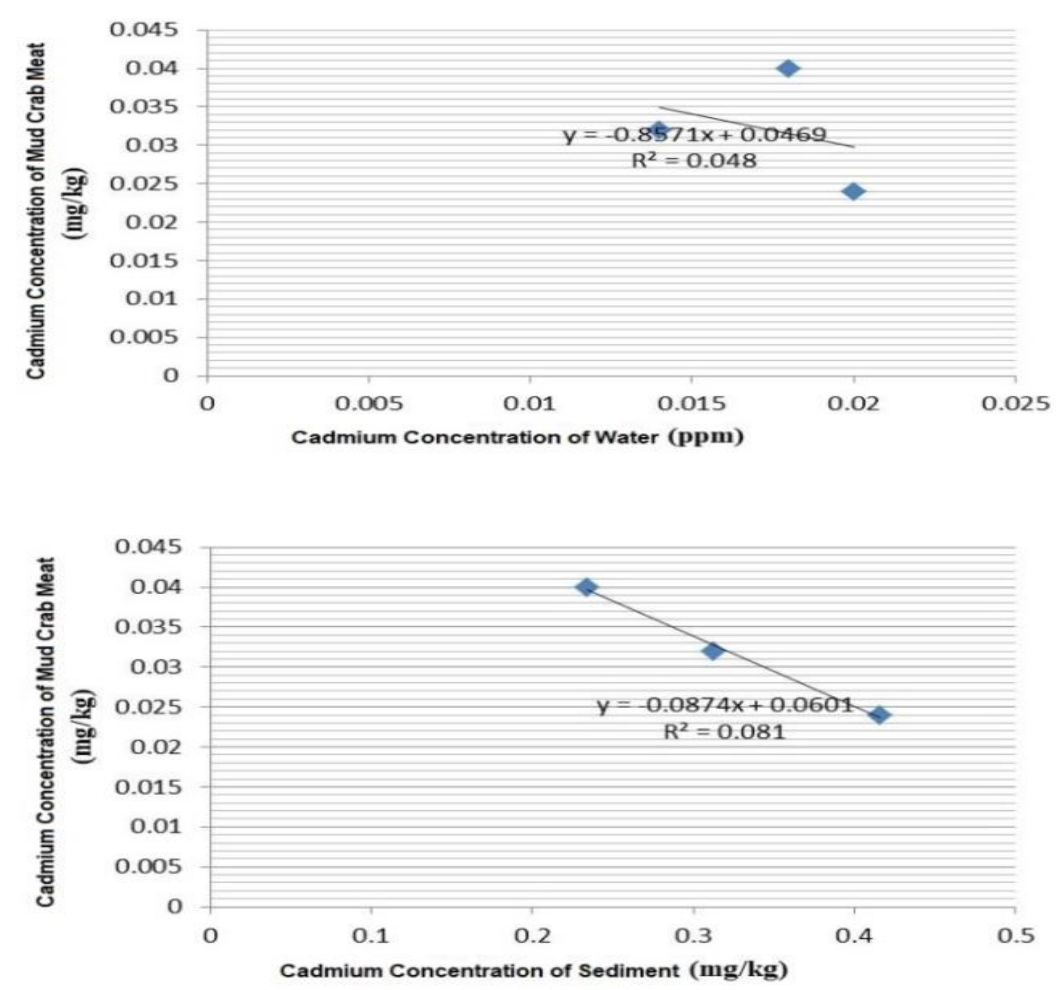

Figure 2. The relation of cadmium concentration between mud crab flesh and water, and the relation of cadmium concentration between mud crab flesh and sediment

\subsection{The Mud Crab Caught During Experiment}

The measurement of carapace wide and the weight of Scylla sp, mud crabs that are caught for three weeks of experiment in Wonorejo river of Surabaya on rainy season shows the different variation of the size. The wide of Scylla sp carapace on each station revealed its average of size between $8,94 \mathrm{~cm}$, $9,83 \mathrm{~cm}$, and $9,99 \mathrm{~cm}$. the weighing of Scylla sp on each station revealed its average size between $147,26 \mathrm{gr}, 172,3 \mathrm{gr}$, and $164,26 \mathrm{gr}$.

Bigger size of Scylla sp is found in station 3. This phenomena occurred as station 3 takes place in estuary area which is near with the beach surrounded by mangroves vegetations within mud substrate. Such condition is an ideal and natural environment for mud crab (Saputri,2018). The size of Scylla sp. Varies from one season to another within fluctuation of environment factors such as; temperature, water, salinity, nutrition, sedimentation, number of waste, predator, and fishing activity (Meynecke and Richards, 2013).

\section{Conclusion}

According to the result of study, the conclusions of this study state that the concentration of cadmium heavy metal (Cd) found in mud crab flesh (Scylla sp.) of Wonorejo river in Surabaya is about 0,024 $0,041 \mathrm{mg} / \mathrm{kg}$. Thus the mud crab (Scylla sp.) found in Wonorejo river of Surabaya is still safe to be consumed by human as the number does not exceed the threshold of cadmium heavy metal waste amount which is $1,0 \mathrm{mg} / \mathrm{kg}$ (SNI 7387: 2009).

\section{References}

ANZECC and ARMCANZ. 2000. Australian and New Zealand Guidelines for Fresh and Marine Water Quality. Australian and New Zealand Environment and Conservation Council dan Agriculture and Resource Management Council of Autralia and New Zealand. Australia: Canberra Act. 126.

Badan Lingkungan Hidup Kota Surabaya. 2011. Laporan Kegiatan Pengendalian Pencemaran Kawasan Pantai Dan Pesisir. Surabaya. 1-5.

Badan Standarisasi Nasional. 2009. SNI 7387: 2009 Tentang Batas Maksimum Cemaran Logam Berat dalam Pangan. 79. 
Dinas Perikanan dan Kelautan Provinsi Jawa Timur. 2014. Laporan Tahunan Statistik Perikanan Tangkap di Jawa Timur. Surabaya. 34.

Dinas Ketahanan Pangan dan Pertanian Kota Surabaya. 2017. Produksi Ikan Laut Menurut Jenisnya (Ton) 2011-2016. Surabaya.

Fatmawatinir., Hamzar, Suryani., Admin, Alif. 2015. Analisis Sebaran Logam Berat pada Aliran Air dari Tempat Pembuangan Akhir (TPA) Sampah Air Dingin. Jurnal Riset Kimia. Universitas Andalas. Padang. 105.

Gunarto. 2004. Konservasi Mangrove Sebagai Pedukung Sumber Hayati Perikanan Pantai. Jurnal Litbang Pertanian. Jakarta. 40-45.

Indrayana, Reandy., M, Yusuf., Aziz, Rifai. 2014. Pengaruh Arus Permukaan Terhadap Sebaran Kualitas Air di Perairan Genuk Semarang. Jurnal Oseanografi. Universitas Diponegoro. Semarang. 652-654.

Mamaribo, H., Rompas, R.J., and Kalesaran, O.J. 2015. Determinasi KandunganCadmium (Cd) di Perairan Pantai Malalayang Sekitar Rumah Sakit ProfKandou Manado. Jurnal Budidaya Perairan. Universitas Sam Ratulangi. Manado. 1-2.

Menteri Negara Lingkungan Hidup. 2004. Keputusan Menteri Nomor 52 Tahun 2004 Tentang Baku Mutu Air Laut. Jakarta. 1497

Meynecke, J.O and R.G. Richards. 2013. A Full Life Cycle and Spatially Explicit Inividual Based Model For The Giant Mud Crab (Scylla serrata): a Case Study From a
Marine Protected Area. ICES J. of Marine Science. 1-15

Mukhtasor. 2007. Pencemaran Pesisir dan Laut. Pradnya Paramita. Jakarta. 50.

Mamboya, F.A. 2007. Heavy Metal Contamination and Toxicity. Stockholm University. 160.

Nowrouzi, M., Pourkhabbaz, A., Rezaei, M. 2012. Bioaccumulation and Distribution of Metals in Sediments and Avicenna Marina Tissues in The Hara Biosphere Reserve, Iran. Bull Environ Contam Toxicol.799-804.

'Permanawati, Yani.,Rina, Zuraida., Ibrahim, Andrian. 2013. Kandungan Logam Berat (Cu, Pb, Zn, Cd, dan Cr) dalam Air dan Sedimendi Teluk Perairan Jakarta. Jurnal Geologi Kelautan. Bandung. 13-14.

Saputri, Mimie.,dan Muammar. 2018. Karakteristik Habitat Kepiting Bakau (Scylla sp.) di Ekosistem Mangrove Silang Cadek Kecamatan Baitussalam, Kabupaten Aceh Besar, Provinsi Aceh. Jurnal Biotik. Unsyiah. Banda Aceh. 7580.

Satori, Djam'an dan Aan, Komariah. 2009. Metodologi Penelitian Kualitatif. Bandung: Alfabeta. 22

Widowati, W. 2008. Efek Toksik Logam Pencegahan dan Penanggulangan Pencemaran. Yogyakarta: Penerbit Andi. 36-37.

Yalcin, G., Narin, I., Soylak, M. 2008. Multivariate Analysis of Heavy Metal Contents of Sediments From Gumusler Creek, Nigde, Turkey. Environmental Geology. 1155-1163. 